\title{
PERCEIVED TASK CHARACTERISTICS AND ITS EFFECT ON EMPLOYEE ENGAGEMENT AT PRIVATE COLLEGES IN SARAWAK
}

\author{
Muhammad Madi Bin Abdullah ${ }^{1}$ \\ School of Business and Management, University College of Technology Sarawak (UCTS), Malaysia. \\ (Email: dr.madi@ucts.edu.my) \\ Lau Hui Lin ${ }^{2}$ \\ School of Business and Management, University College of Technology Sarawak (UCTS), Malaysia. \\ (Email: lauhuilin@ucts.edu.my)
}

Received date: $16-10-2019$

Revised date: 20-10-2019

Accepted date: 29-10-2019

Published date: 12-12-2019

To cite this document: Abdullah, M. M., \& Lau, H. L. (2019). Perceived Task Characteristics and Its Effect on Employee Engagement at Private Colleges in Sarawak. International Journal of Modern Trends in Social Sciences, 2(10), 22-34.

DOI: $10.35631 /$ IJMTSS.210003

\begin{abstract}
This study examines five perceived task characteristics variables (decisionmaking autonomy, task variety, task significance, task identity, feedback from job) and its effect on employee engagement at six private college employees in Sarawak. Despite extensive research on employee engagement, very little empirical research has examined this area of study specifically in the context of Sarawak private colleges. A survey questionnaire was employed to collect the data. A total of 284 responses were analysed using SPSS version 22.0. The results of this study revealed that only feedback from job, task identity and decision-making autonomy are significantly and positively associated with employee engagement. Task significance and task variety were not significantly related to employee engagement. Most importantly, decision-making autonomy was perceived as a dominant task characteristic for employee engagement; it was associated with significant improvements on private colleges' employee engagement. This study contributes to a better understanding of the effect of perceived task characteristics on employee engagement among private colleges in Sarawak. The implications for practice and suggestions for future research are discussed.
\end{abstract}

Keywords: Task Characteristics, Employee Engagement, Sarawak

\section{Introduction}

According to Shuck \& Wollard (2010), employee engagement is an individual employee's cognitive, emotional and behavioural state directed toward achieving desired organizational outcomes. Engagement at work also was defined by Kahn (1990) as the harnessing of organizational members to their work roles. In engagement, people employ and express 
themselves physically, cognitively, and emotionally during their job performances. Csikszentmihalyi $(1975,1990)$ has advanced the concept of flow to engagement in organizational behaviour in which it was referred as the holistic sensation that people feel when they act with total involvement.

Kular et. al. (2008) in their studies have asserted that the existence of assorted explanations of significance, decision making autonomy and feedback in a job context. The job characteristics model (JCM) posits that the psychological states of meaningfulness, experienced responsibility, and knowledge of results mediate the relationship between the job design facets and organizational outcomes (Hackman \& Oldman, 1980). There is an increasing awareness that employee engagement is pivotal to successful commercial and business performance, where engaged employees are the backbone of good working environments where people are industrious, ethical and accountable (Levinson, 2007).

Sarawak government has been gearing efforts to transform the economy in the next few years (2025) in order to bring the state to a high level of industry growth. Hence, the development of strong, engaged and productive workforce is critical in order to support the government effort to achieve the objectives. In connection with this, the education industry in Sarawak is becoming one of the major players in the high level of industry growth in line with Sarawak's vision and commitment in establishing a world class institutions of higher learning to spearhead the development and production of technical human resource for Sarawak Corridor of Renewable Energy (SCORE). The Sarawak Corridor of Renewable Energy (SCORE) is a new development corridor in middle region of Sarawak. It was launched on 11 February 2008 and accounts for $90 \%$ of Sarawak total foreign direct investment of RM9.6 billion, where about $87.2 \%$ were from foreign investors. Hence, demand for qualified academic and technical qualifications are highly needed in order to meet the demand of state industries by year 2030 . Moreover, middle region is also one of the main gateway to SCORE and therefore, all the higher institutions in middle region plays an instrumental roles to ensure that graduates are equipped with the knowledge and skills required by the industries within SCORE since higher institutions are here to complement the growth and fulfil the human resource and industrial needs of SCORE.

The significant study regarding to the factors that affect employee engagement was carried out by Kahn on the psychological conditions of personal engagement and disengagement at work context (Kular et al., 2008; Saks, 2006). In his research, Kahn (1990) defined personal engagement as the harnessing of organization members' selves to their work roles; in engagement, people employ and express themselves physically, cognitively, and emotionally during role performance. He also stated that there are three psychological conditions which might be associated with employee engagement, specifically meaningfulness, safety, and availability. Therefore, organisations with higher engagement levels tend to have lower employee turnover, higher productivity, higher total shareholder returns and better financial performance (Baumruk, 2006).

\section{Problem Statement}

Most of the studies concerning employee engagement were executed in western countries (e.g. Groblena, 2019; Breevaart et al., 2014, Aon Hewitt, 2011; Bakker et al., 2011; Gruman \& Saks, 2011; Hallbesleben, 2011; Shuck, 2011; Schaufeli, \& Bakker, 2010). Krishnan et al. (2013), for instance in their study have examined job/task characteristics as main antecedents/predictors to employee engagement. 
However, no study has ever been made so far on the employee engagement of the private colleges, especially in the middle region of Sarawak. This motivate the researchers to carry out the pioneer study about employee engagement for the six private colleges located at the middle region of Sarawak. Since middle region is the main gateway to SCORE, employees engagement at private colleges plays a crucial part to ensure that graduate are equipped with the good knowledge and skills required by the industries within SCORE. According to Liliana \& Sandra (2019), organizations which are aware of the importance of retain and create happiness at work can create an internal experience for their workforce. When employees are happier at work, they tend to take part of the ownership of their organizations and become more focused on people and the value that they can add to the products designed, created, and delivered by them. Fukuyama (2015) also argues that the ability to develop relationships of spontaneous sociability could predict whether an organization will compete effectively. In other words, organization must has the ability to make associations and partnership with employees to ensure that organization itself has the competent, open, honest and reliable.

Hence, the gap in terms of location are often consummated by embarking the study on the factors affecting employee engagement in Sarawak specifically in private higher education sector. Thus, the principal aim of this study is to examine the relationship between perceived task characteristics variables and employee engagement among employees at six private colleges in middle region of Sarawak.

\section{Literature Review and Hypotheses Development}

Kahn (1990) was the first author that introduced the concept of employee engagement at work to the academic realm. He suggested that people may use various degree of their physical, emotional and cognitive development in the workplace. Unlike the concepts of job involvement, organizational commitment and self-estrangement, Khan wanted to examine the essence of what it actually means to be present psychologically in particular situations. In general, employee engagement is a level of commitment and involvement an employee has towards the organization and its values. When an employee is engaged with the task given, he or she will be aware of his responsibility in the business goals and being motivated alongside his colleagues for the success of the organizational goals. Katz \& Kahn (1966) have referred to the concept of engagement in their work which is related to the organizational effectiveness. Meanwhile, it has been mentioned in specific as one of a number of needs to be developed to provide an innovative and cooperative work environment that will lead to employee performance and effectiveness.

According to Baumruk (2004), employee engagement has been emphasized and it is considered to be the most powerful factor in the workplace. On the other hand, Schaufeli \& Bakker (2010), described employee engagement as the psychological state that accompanies the behavioural investment of personal energy. An engaged employee is intellectually and emotionally bound with the organization, passionate about the goals and feel committed to live by its values and norms. Job characteristics theory (Hackman \& Oldham, 1976, 1980) has identified the relationship between job characteristics and individual responses to work. The theory specifies the task condition in which individuals are predicted to prosper in their work. According to Hackman \& Oldham $(1976,1980)$, there are five job dimensions prompting three psychological states that lead to some beneficial personal and work outcomes. The five core job characteristics are: 1. Task identity: Seeing a whole piece of work. Employees can complete a task from beginning to end with an identifiable outcome; 2. Task significance: Importance of the job. The characteristic is determined by the impact the employee's work has within or outside the organization; 3 . Skill variety: The degree to which employees are able to do a 
number of different tasks using many different skills, abilities, and talents; 4. Decision Making Autonomy: The degree to which employees have control over their work; and 5. Employee Feedback: The degree to which the job offers information to employees regarding performance and work outcome. Rai et al. (2017) in their study have found that all these five task/job characteristics showed a positive relationship with employee engagement.

\section{Relationship between Decision Making Autonomy and Employee Engagement}

According to Mueller et al. (1999), participation in decision making may increase employee involvement and engagement in how those task characteristics are engaged. By involving in decision making, it may mediate the influences of autonomy on satisfaction and commitment of employees. Employees that are involved in decision making will decrease the role of ambiguity and conflict and increase knowledge of results so uncertainty is reduced, providing motivational benefits that will improve employees' performance and productivity (Degeling et.al, 2000; Healy \& Mckay, 2000). Furthermore, employee involvement in decision making encourages job satisfaction, which increases productivity through bringing about a higher quality of motivation and working capabilities at times of implementation (Lawrence et al, 2014). Krishnan et al. (2015) in their study have found that there is a positive relationship between decision making autonomy and employee work engagement.

Furthermore, Knoop (1991) stated that involvement in decision making will give a greater meaning to employees and support work being in purposeful and meaningful work. Locke (1976) also stated that employee engagement is based on their perceptions of how well the job provides important outcomes as well as employee's future expectations. While employees involving in decision making can increase performance effectiveness, it must be supported by the human resource practices that reward and recognize the changes. Thus, the following hypothesis is proposed.

H1: Decision making autonomy is significantly related to employee engagement.

\section{Relationship between Task Variety and Employee Engagement}

There are theoretical and empirical bases for linking every job style aspect to engagement. A job holder whose tasks are varied, therein the incumbent is needed to complete numerous activities throughout the work day, can possibly feel challenged by his or her work. Hackman \& Oldham (1976) likened the impact of selection at work with parlor games, puzzles, and recreational activities as they faucet into the intellectual or motor skills of those that do them. Once employment involves a spread of tasks, the dutiful incumbent might expertise a way of energetic reference to work activities. Research has established that monotony fuels distress among jobholders (Melamed et al., 1995). Individuals who perceive to be engaged in a variety of tasks consider their work to be interesting (Morgeson \& Humphrey, 2006) and motivational (Ryan \& Deci, 2000). This can lead to positive association of task variety with employee engagement. Thus, the following hypothesis is proposed.

$\mathrm{H} 2$ : Task variety is significantly related to employee engagement.

\section{Relationship between Task Significance and Employee Engagement}

A job with a high level of task significance is one in which the employees believes that the job has a demonstrable impact on others (Hackman \& Oldham 1980). Grant (2008) states that if employees are aware of the impact of their work on others, they are likely to invest in high levels of effort and persist in completing their work and are more engaged. Krishnan et al. (2015) and Grobelna (2019) in their studies have found that there is a positive relationship 
between task significance and employee work engagement. An employee whose tasks are perceived as important considers the work to be purposeful and valuable and may be willing to enforce high levels of energy while working and remain resolute in the face of task difficulties. Based on this argument, the following hypothesis is proposed.

H3: Task significance is significantly related to employee engagement.

\section{Relationship between Task Identity and Employee Engagement}

An individual whose job relates with their responsibility for a whole piece of meaningful work is likely to feel a connection with the job. Kahn (1990) has stated that an individual who thinks that being responsible toward their work may reflect their sense of self is more engaged at the workplace. Task identity refers to helping employees to understand the relation between their job and other activities in the organization. When some employees are not being responsible or are not aware of the relation between their job and other activities in organizations, they might not feel like they have achieved something. But, when they feel responsible and know the relation between their jobs, they might feel that what they do is really important and meaningful. Job characteristics with motivational potential like task identity will lead to meaningful work and high productivity (Hackman \& Oldham, 1980; Fried \& Ferris, 1987) as cited by Albrecht (2010). Shantz et al. (2013) have commented that an individual may be connected with a job if he/she is responsible for a whole piece of meaningful work.

Hackman \& Oldham (1975) defined that an individual with higher needs would respond more positively to enrich job. Task identity is when the whole task are combine to form a complete job. Employers may obtain employee's interests when designing the jobs. An individual is able to perceive their work as meaningful if they can see how their job contributes to the final product. This happens when a person is able to complete the whole task from start to finish (Hackman \& Oldham, 1980). Thus, the following hypothesis is proposed.

H4: Task identity is significantly related to employee engagement.

\section{Relationship between Employee Feedback and Employee Engagement}

Locke \& Latham (1990) argued that feedback will encourage people to do their job confidently. When a person receives feedback from colleagues, he or she is able to see clearly how effective their job performance is. Employees need continuous feedback to improve their job performance and its effectiveness. It should be obtained directly from the work-related activities, be simple and impersonal. Pinder (1998) mentioned that more immediate feedback is less inclined to dilution by any alternative influences. Feedback from a superior is also essential to employees so that they may increase their job performance. Feedback from the job is predicted to be related to the psychological state which is knowledge of the actual result of work. Krishnan et al. (2015) in their study have found that there is a positive relationship between feedback and employee work engagement.

Hackman \& Oldham (1980) stressed that the knowledge result from the work itself may increase a person's pride and enthusiasm in their own work. Individuals who receive information about the effectiveness of their effort from the job have higher levels of engagement. On top of that, employees are far more content, put forth extra effort, stay employed longer, and have enormously better relationships with their manager if their leader provides effective feedback (Zenger \& Folkman, 2017). Based on this argument, the following hypothesis is proposed. 
H5: Feedback from job is significantly related to employee engagement.

Thus, the conceptual framework of the present study is shown in Figure 1.

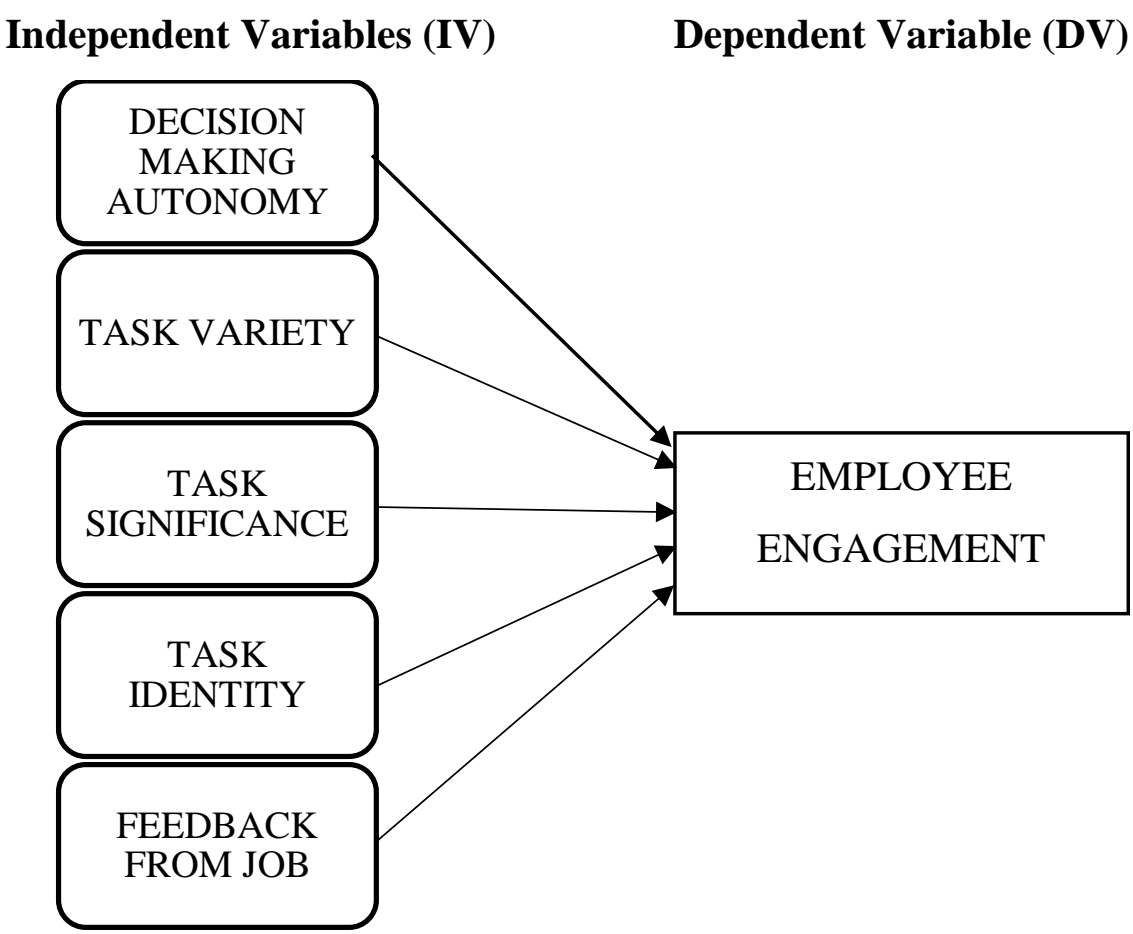

Source: (Author)

Figure 1: Conceptual framework

\section{Methodology}

This study employed survey questionnaire which is the most common data collection method to examine the effect of perceived task characteristics on employee engagement at selected six private colleges in Sarawak. The target population for this study consists of all employees of private colleges in Sarawak (Kolej Laila Taib (Sibu), Riam College (Miri), Fajar International College (Miri), IBS (Miri), SATT College (Kuching) and SIDMA College (Kuching)). The population size (N) for this study is 1020. According to Krejcie and Morgan (1970) the sample size required is almost close to 278. The questionnaires were distributed to employees who were a required to fill in the details.

All the variables in the study were measured using the scales adopted from work design questionnaire developed by Morgeson \& Humphrey (2006). Fifteen samples of questionnaires were given to employees in Kolej Laila Taib (Sibu) for the purpose of pilot survey. The results revealed that the Cronbach's Alpha values for all variables ranged from 0.812 to 0.950 indicated a good inter-item, consistency and stability of data collected.

\section{Findings and Discussion}

The collected data were analysed using social science statistics software (SPSS) version 22.0. Only a total number of 300 sets of questionnaires have been randomly selected and distributed among employees at six private colleges in Sarawak. Out of 300 sets of questionnaires, 284 were returned and considered appropriate to be utilized for the final analysis. 
First, a principal component factor analysis with Varimax Rotation was utilized to validate the construct validity of the variables and the results are presented in Table 1 . There was no cross loading of items within the factor analysis. The factor analysis matrices showed that all the six variables were uni-factorial.

Table 1: Summary of Factor Matrix

\begin{tabular}{|c|c|c|c|c|c|c|c|}
\hline Constructs & $\begin{array}{c}\text { Item } \\
\text { Loading }\end{array}$ & $\begin{array}{l}\text { Eigen } \\
\text { Value }\end{array}$ & $\begin{array}{c}\% \text { of } \\
\text { Variation } \\
\text { Explained }\end{array}$ & $\begin{array}{c}\text { Cronbach's } \\
\text { alpha }\end{array}$ & KMO & BTS & $\begin{array}{c}\text { p- } \\
\text { value }\end{array}$ \\
\hline $\begin{array}{l}\text { Decision } \\
\text { Making } \\
\text { Autonomy }\end{array}$ & $\begin{array}{c}0.790- \\
0.883\end{array}$ & 2.114 & 70.456 & 0.790 & 0.700 & 264.094 & 0.0005 \\
\hline Task Variety & $\begin{array}{c}0.847- \\
0.887\end{array}$ & 2.986 & 74.657 & 0.887 & 0.777 & 676.070 & 0.0005 \\
\hline $\begin{array}{l}\text { Task } \\
\text { Significance }\end{array}$ & $\begin{array}{c}0.650- \\
0.839\end{array}$ & 2.347 & 58.673 & 0.700 & 0.645 & 360.030 & 0.0005 \\
\hline Task Identity & $\begin{array}{c}0.822- \\
0.889\end{array}$ & 2.941 & 73.536 & 0.878 & 0.814 & 602.840 & 0.0005 \\
\hline $\begin{array}{l}\text { Feedback from } \\
\text { Job }\end{array}$ & $\begin{array}{c}0.872- \\
0.910\end{array}$ & 2.382 & 79.398 & 0.873 & 0.731 & 424.152 & 0.0005 \\
\hline $\begin{array}{l}\text { Employee } \\
\text { Engagement }\end{array}$ & $\begin{array}{c}0.708- \\
0.854\end{array}$ & 5.744 & 63.826 & 0.928 & 0.919 & 1781.397 & 0.0005 \\
\hline
\end{tabular}

The eigenvalues ranged from 2.114 to 5.744 . The item loading for each factor is rather high with a minimum loading of 0.650 confirming the validity of all the six constructs. The Cronbach's Alpha values varies from 0.700 to 0.928 and considered to be good (Peterson, 1994). Bartlett's test of sphericity results show that data do not produce identity matrix and are thus considered approximately multivariate normal and acceptable for factor analysis and other multivariate statistical tests. The Kaiser-Meyer-Olkin (KMO) values are all above 0.70 indicating that the distribution of values is adequate for running factor analysis (Peterson, 1994). The Skewness and Kurtosis values are -0.737 and 1.336 which fall well between +2 and -2 and also the Kolmogorov-Smirnov values is 0.115 which is above 0.05 and it is larger than $\mathrm{p}$-value of 0.05 . This confirm that the population from which the sample is drawn is normally distributed.

Table 2 depicts the detailed summary of correlation between five independent variables which are Task Variety, Feedback from job, Task Identity, Decision Making Autonomy and Task Significance with dependent variable, Employee Engagement.

Table 2: Correlation Matrix

\begin{tabular}{|c|c|c|c|c|c|c|}
\hline Variables & 1 & 2 & 3 & 4 & 5 & 6 \\
\hline $\begin{array}{l}\text { 1. Decision Making } \\
\text { Autonomy }\end{array}$ & 1.000 & & & & & \\
\hline 2. Task Variety & $0.405 * *$ & 1.000 & & & & \\
\hline 3. Task Identity & $0.464 * *$ & $0.417 * *$ & 1.000 & & & \\
\hline
\end{tabular}


4. Task Significance $\quad 0.340 * * \quad 0.418^{* *} \quad 0.396 * * 1.000$

5. Feedback from Job $\quad 0.455^{* *} \quad 0.340 * * \quad 0.572 * * \quad 0.335^{* *} \quad 1.000$

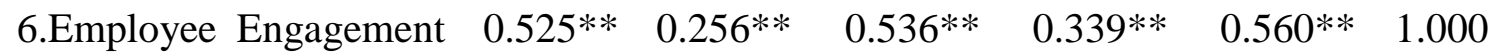

**Correlation is significant at the 0.01 level (2 tailed)

Source: (Author)

Table 2 shows that all the five task characteristics (five independent variables) were significantly positively associated with the dependent variable (employee engagement). Out of all the correlations, all coefficients are larger than 0.30 . There are no high correlations of 0.90 or above. Hence, collinearity and multicollinearity do not present data problems in this research (Hair et al., 1998). These results show that the five independent variables have a positive correlation with employee engagement. Therefore, the five variables may have impact on employee engagement. To find out the best set of predictors of Employee Engagement, a fivepredictor multiple linear regression model was proposed. The five-predictor variables are task variety $\left(\mathrm{X}_{1}\right)$, feedback from job $\left(\mathrm{X}_{2}\right)$, task identity $\left(\mathrm{X}_{3}\right)$, decision making autonomy $\left(\mathrm{X}_{4}\right)$ and task significance $\left(\mathrm{X}_{5}\right)$. The dependent variable is employee engagement $(\mathrm{Y})$. The equation of the proposed multiple linear regression model is as follows:

$$
\begin{gathered}
Y=b_{0}+b_{1} X_{1}+b_{2} X_{2}+b_{3} X_{3}+b_{4} X_{4}+b_{5} X_{5}+e \\
\text { Where: } b_{o}=\text { Constant, } e=\text { Error }
\end{gathered}
$$

Table 3 shows that the Durbin-Watson of 1.826 falls within the acceptable range $(1.5<\mathrm{D}>$ $2.5)$, indicating that there is no autocorrelation problem in the data and that the error term is independent. From the analyses, it can be concluded that the multiple regression analysis model generated in this study meets the five assumptions required to ensure validity of its significance test (Ooi et.al, 2011).

Table 3: Results of Multiple Linear Regression

\begin{tabular}{lccccc}
\hline & $\begin{array}{c}\text { Beta } \\
\text { (Unstandardized } \\
\text { Coefficients) }\end{array}$ & $\begin{array}{c}\text { Std. } \\
\text { Error }\end{array}$ & $\begin{array}{c}\text { Beta } \\
\text { (Standardized } \\
\text { Coefficients) }\end{array}$ & t-value & p-value \\
\hline Constant & 0.653 & 0.264 & 0.538 & 2.476 & 0.0140 \\
Task Variety & -0.108 & 0.058 & -0.098 & -1.865 & 0.0630 \\
$\begin{array}{l}\text { Feedback from } \\
\text { Job }\end{array}$ & 0.292 & 0.056 & 0.296 & 5.237 & 0.0005 \\
Task Identity & 0.247 & 0.061 & 0.238 & 4.049 & 0.0005 \\
$\begin{array}{l}\text { Decision } \\
\text { Making }\end{array}$ & 0.295 & 0.055 & 0.290 & 5.388 & 0.0005 \\
$\begin{array}{l}\text { Autonomy } \\
\text { Task }\end{array}$ & 0.103 & 0.059 & & & \\
Significance & & & & & \\
R=0.67, $\mathrm{R}^{2}=0.450 ;$ Adj. $\mathrm{R}^{2}=0.440 ; \mathrm{F}=45.558 ; \mathrm{p}=0.0001 ;$ Durbin- Watson $=1.826$ & & \\
Source: (Author) & & & & & \\
\end{tabular}

Based on the stepwise method, only three predictor variables were found to be of significance in explaining employee engagement. The three predictor variables are feedback from job, task identity and decision making autonomy. The remaining two variables, task variety and task significance did not contribute in significance $(\mathrm{t}<1.96, \mathrm{p}>0.05)$ to the variation of the dependent variable (employee engagement). The R-squared of 0.450 implies that the three independent variables (feedback from job, task identity and decision making autonomy) were 
able to explain about 45 percent of the variation in employee engagement. This is considered a very good and respectable result. The F-statistics is 45.558 which is larger and the corresponding p-value is highly significant (0.0001) or lower than the alpha value of 0.05 . This results confirm that only three task characteristics (feedback from job, task identity, decision making autonomy) have a significant positive impact on the level of employee engagement. Out of this, decision making autonomy has the strongest significant positive influence on employee engagement $(b=0.295)$.

The unstandardized coefficient and the corresponding p-value for decision making autonomy were 0.295 and 0.0005 respectively. Thus, there is a significant positive relationship between these two variables. Therefore, H1 is supported. In the context of this study, the decision making autonomy leads to employee's psychological ownership at work. Autonomy in decision making gives employees in private colleges a chance to use their personal initiative or judgement in carrying out their work and provide them with significance feedback in making their own decisions. According to Hackman \& Oldham (1976), the work outcomes of a jobholder with high levels of autonomy depend on the individual's effort and decisions, rather than on instructions from the person's superior or job procedures. When employees believe their management will encourage employee to be more participative in decision making it will improve employee's effort which benefits their job performance, engagement and commitment to their work.

The unstandardized coefficient for task variety was -0.108 and the corresponding $p$-value was 0.063 which is greater than the threshold value of 0.05 . Therefore, there is statistically no significant relationship. Therefore, $\mathrm{H} 2$ of this study is not supported. According to the research by Zaniboni et al. (2013), they mentioned in their study about the differences between younger and older workers in relation to task variety in engaging employees. In this study, due to the low context in relationship between task variety and employee engagement it can relate with younger and older workers. Most of the younger employees in private colleges in Sarawak prefer task variety whereas the older employees are more focus on their skill variety. On the other hand, younger workers see task variety as their path to develop their job skills to advance their career. Meanwhile, older workers who have already acquired these skills want to apply their skills. This will encourage better engagement and will decrease in turnover.

Besides, low context relationship between task variety and employee engagement may relate to the job task given to the employees in workplace. According to James et al., (2011), certain factors can give effect toward employees instead of depending more on their ages and tasks given. The researchers also looked at four influences, supervisor support and recognition, schedule satisfaction, job clarity and career development and promotion. In private colleges in Sarawak, it was found that most of the employee have a low context in these four influences that being mentioned by the researchers. When the task given increases, it can result in a low engagement between employees and their jobs because certain employees could not engage with a lot of tasks that had been given to them. The employees felt that there were no encouragements for them to do a lot of tasks and caused negative relationship between task variety and employee engagement.

The unstandardized coefficient for task significance was 0.103 and the corresponding p-value was 0.085 which is greater than the thresh hold value of 0.05 . Therefore, there is statistically no significant relationship between these two variables. Hence, H3 of this study is not supported. In the context of this study, task significance is the degree to which a college job affects the lives of other employees. The effect of this variable may be either within the 
organization or outside. According to Hackman \& Oldham (1980), a job with a high level of task significance will affect the job holder to believe that their jobs have a demonstrable impact on the lives of others. When a job significantly improves their self-confidence to do their works either physical or psychological well-being of others, the employees will feel that their work is more engaged and meaningful, compared to those work activities that have a negligible effect on others.

Thus, employees in private colleges in Sarawak felt that the results of their works were not able to make any differences in his or her jobs which were considered insignificant to the lives of others. In contrast, when the employees have low task significance, they are more reluctant to contribute their skills with organization or outsider. In other words, they prefer the impact of their jobs more than impact on people outside the organization.

The unstandardized coefficient for task identity was 0.247 and the corresponding p-value was 0.0005 which is lesser than the thresh hold of 0.05 . Thus, there is a statistically significant positive relationship between this variable. Therefore, $\mathrm{H} 4$ is supported. In the context of this study, task identity is the extent to which college employees complete a whole and identifiable piece of work all the way through to the end, so that the outcome is visible. Individuals whose job that enable them to be responsible for their work is likely to feel a connection with the job. According to Kahn (1990), individuals who feel able to give and receive from work tasks that reflect their sense of self are more engaged at workplace. Based on the previous studies, if employee felt satisfied in their work environment, it will give a good significance in task identity. Most employees in private colleges in Sarawak find their jobs more meaningful and they are involved in the whole process rather than just being responsible for part of it.

Finally, the unstandardized coefficient value for feedback from job was 0.292 and the corresponding p-value was 0.0005 . Therefore, H5 in this study is supported. In the context of this study, employees in private colleges in Sarawak felt that the job itself provides feedback and information towards their job performance in the workplace. According to Hackman \& Oldham (1980), the knowledge of results and feedback from the work itself can increase a person's pride and enthusiasm in their work. Feedback is a knowledge of the actual result of work activities. When a job is designed to provide employees with better information about the effects of their actions in the workplace, they are better able to develop an understanding of how well they have performed and such knowledge may improve their effectiveness. Therefore, employees are far more content, put forth extra effort, stay employed longer, and have enormously better relationships with their manager if their leader provides effective feedback (Zenger \& Folkman, 2017).

\section{Implications, Limitations and Suggestions for Future Research}

This study has suggested that task characteristics variables (decision making autonomy, task identity and feedback from job) significantly and positively influence employee engagement whereas the other two variables (task variety, task significance) do not have any influence on employee engagement. This implies that by focusing and implementing the three independent variables (decision making autonomy, task identity, feedback from job), employers at private colleges would be able to promote and improve the overall levels of their employee engagement.

This study is subjected to some limitations. First of all, this study is based on a small sample size since it involved only a few selected private colleges in Sarawak. Second, the study is cross-sectional in nature. Third, several other work related factors which may impact on 
employee engagement have not been considered in the study. Given these limitations, further research might need to be carried out in three directions. First, other private and government based colleges in Sarawak are to be included. Second, a longitudinal research would complement this work to support these relationships on a longitudinal basis. Third, future studies could look into the possible inclusion of other work related factors (social support, physical demand, supervisor support, communication, compensation) in relation to employee engagement.

\section{Conclusion}

The results of the study confirm that if the management at private colleges in Sarawak can ensure that employees are provided with high decision making autonomy, task identity and feedback from job, then employees will be able to engage more with their own work leading to positive work performance outcomes and low deviance levels.

\section{References}

Albrecht, S.L. (2010). New horizons in management. Handbook of employee engagement: Perspectives, issues, research and practice. Northampton, MA: Edward Elgar Publishing.

Aon Hewitt (2011). OCL Employee Engagement Survey. Results Presentation and Action Planning Workshop. Available at the library, OCL, Rajgangpur, Orissa.

Bakker, A.B., S.L. Albrecht., \& M.P. Leiter (2011). Work Engagement: Further Reflections on the State of Play. European Journal of Work and Organizational Psychology, 20(1), 74-88.

Baumruk, R. (2004). The missing link: the role of employee engagement in business success, Workspan.

Baumruk, R. (2006). Why managers are crucial to increasing engagement, Strategic HR Review, January/February.

Breevaart, K., Bakker. A.B., \& Demerouti, E. (2014). Daily Self-Management and Employee Work Engagement. Journal of Vocational Behaviour, 84(1), 31-38.

Csikszentmihalyi, M. (1975). Beyond boredom and anxiety (1st Ed.), San Francisco, US: Jossey- Bass Publishers.

Csikszentmihalyi, M. F. (1990). The psychology of optimal experience (1st Ed.), New York: Harper \& Row.

Degeling, P., Hill, M., Kennedy, J., Coyle, B., \& Maxwell, S. (2000). A cross-national study of differences in the identities of nursing in England and Australia and how this has affected nurses' capacity to respond to hospital reform, Nursing Inquiry, 7(2), 120-35.

Fukuyama, F. (2015). Trust: The Social Virtues and creation of Prosperity. New York: Free Press.

Grant, A. M. (2008). The significance of task significance: Job performance effects, relational mechanisms, and boundary conditions. Journal of Applied Psychology, 93, 108-124.

Grobelna, A. (2019). Effects of individual and job characteristics on hotel contact employees' work engagement and their performance outcomes: A case study from Poland. International Journal of Contemporary Hospitality Management, 31(1), 349-369.

Gruman, J.A., \& Saks, A.M. (2011). Performance Management and Employee Engagement. Human Resource Management Review, 21(2), 123-136.

Hackman, J. R., \& Oldham, G. R. (1975). The job diagnostic survey: an instrument for the diagnosis of jobs and the evaluation of job redesign projects. Department of Administrative Sciences: Yale University.

Hackman, J. R., \& Oldham, G. R. (1976). Motivation through the Design of Work: Test of a Theory. Organizational Behaviour and Human Performance, 16, 250-279. 
Hackman, J., \& Oldham, G. (1980). Work redesign, Reading, MA: Addison-Wesley.

Hair, J.F., Andersson, R.E., Tatham, R.L., \& Black, W.C. (1998). Multivariate data analysis. New Jersey: Prentice Hall International Inc.

Hallbesleben, J.R.B. (2010). A meta-analysis of work engagement: Relationships with burnout, demands, resources, and consequences. In: Work Engagement: A Handbook of Essential Theory and Research (eds A.B.Bakker and M.P. Leiter) pp.102-117. Psychology Press, New York.

Healy, C. M., \& McKay, M. F._(2000). Nursing stress: the effects of coping strategies and job satisfaction in a sample of Australian nurses. Journal of Advance Nursing. 31(3), 6818.

James, B.D., Wilson, R.S., Barnes, L.L., \& Bennett, D.A. (2011). Late-life social activity and cognitive decline in old age. Journal of International Neuropsychology Social, 17(6), 998-1005

Kahn, W. A. (1990). Psychological conditions of personal engagement and disengagement at work. Academy of Management Journal, 33(4), 692-724.

Katz, D., \& Kahn, R.L. (1966). The Social Psychology of Organizations. New York: Wiley.

Knoop, R.T. (1991). Achievement of work values and participative decision making, Psychological Reports, 58, 775-781.

Krejcie, R.V., \& Morgan, D.W. (1970). Determining Sample Size for Research Activities. Educational and Psychological Measurement, 30, 607-610.

Krishnan, R., Ismail, S., Samuel, R., \& Kanchymalay, K. (2013). The mediating role of work engagement in the relationship between job autonomy and citizenship performance. World Journal of Science, 3(3), 120-131.

Krishnan, R., Ismail, S., Ismail, I., Muhammed, R.N., Muthusamy, G., \& Kanchymalay, K. (2015). Employee work engagement: Understanding the role of job characteristics and employee characteristics. Journal of Applied Environmental Biological Science, 4(10S), 58-67.

Kular, S., Gatenby, M., Rees, C., Soane, E., \& Truss, K. (2008). Employee Engagement: a literature review. Kingston University, Kingston.

Liliana \& Sandra (2019). The Importance of Employees' Engagement on the Organizational Success. Journal of Promotion Management, 25(3), 328 - 336.

Lawrence, Malefane, K., Lebusa, J., \& Joubert, P. (2014). Employee Involvement in DecisionMaking: A Case at One University of Technology in South. Mediterranean Journal of Social Science, Vol 5, No. 27.

Levinson, E. (2007). Developing High Employee Engagement Makes Good Business Sense, www.interactionassociates.com.

Locke, E.A. (1976). The nature and causes of job satisfaction, in Dunnette, M.D. (Ed.), Handbook of Industrial and Organizational Psychology, Rand McNally: New York, NY.

Locke, E. A., \& Latham, G. P. (1990). A theory of goal setting \& task performance. Englewood Cliffs, NJ, US: Prentice-Hall, Inc.

Melamed, S., Ben-Avi, I., Luz, J., \& Green, M. (1995). Objective and subjective work monotony: effects on job satisfaction, psychological distress, and absenteeism in bluecollar workers. Journal of Applied Psychology, 80(1), 29-42.

Morgeson, F. P., \& Humphrey, S. E. (2006). The Work Design Questionnaire (WDQ): Developing and validating a comprehensive measure for assessing job design and the nature of work. Journal of Applied Psychology, 91, 1321-1339.

Mueller, C.W., Finley, A., Iverson, R.D., \& Price, J.L. (1999). The effects of group racial composition on job satisfaction, organizational commitment, and career commitment: The case of teachers. Work and Occupations, 26(2), 187-219 
Ooi, K., Abdul Rahman, T., Lin, B. T. B.-I., \& Yee-Loong., C. A. (2011). Are TQM practices supporting customer satisfaction and service quality? Journal of Services Marketing, 410-419.

Peterson, R.A. (1994). A meta-analysis of Cronbach's coefficient alpha. Journal of Consumer Research, 21, 381-391.

Pinder. C. C. (1998). Work Motivation in Organizational Behavior. Upper Saddle River, NJ: Prentice Hall.

Rai, A., Ghosh, P., Chauhan, R., \& Mehta, N.K. (2017). Influence of job characteristics on engagement: does support at work act as moderator? International Journal of Sociology and Social Policy. 37(1/2), 86-105.

Ryan, R., \& Deci, E. (2000). Self-determination theory and the facilitation of intrinsic motivation, social development and well-being. American Psychologist, 55(1), 68-78.

Saks, A.M. (2006). Antecedents and consequences of employee engagement, Journal of Managerial Psychology. 21(7), 600-619.

Schaufeli, W.B., \& Bakker, A.B. (2010). Defining and measuring work engagement: bringing clarity to the concept, in Bakker, A.B. and Leiter, M.P. (Eds), Work Engagement: A Handbook of Essential Theory and Research, Psychology Press, Hove, NY.

Shantz, A., Alfes, K., Truss, C., \& Soane, E. (2013). The role of employee engagement in the relationship between job design and task performance, citizenship and deviant behaviours. The International Journal of Human Resource Management, 24(13), 26082627.

Shuck, B., \& Wollard, K.K. (2010). Employee engagement and HRD: a seminal review of the foundations, Human Resource Development Review.

Shuck, B. (2011). Four Emerging Perspectives of Employee Engagement: An Integrative Literature Review. Human Resource Development Review, 10(3), 304-328.

Zaniboni, S., Truxillo, D.M., \& Fraccaroli, F. (2013). Differential effects of task variety and skill variety on burnout and turnover intentions for older and younger workers, European Journal of Work and Organizational Psychology, 22(3), 306-317.

Zenger, J., \& Folkman, J. (2017). How a manager drive results and employee engagement at the same time. Harvard Business Review. 